\title{
Konstruksi Instrumen Penilaian Baca Tulis Quran (BTQ) di IAIN Pekalongan
}

\author{
Ma'mun \\ Fakultas Ushuludin, Adab dan Dakwah IAIN Pekalongan \\ e-mail:mamun_sdn@yahoo.com
}

\begin{abstract}
This study aims to develop a valid BTQ matriculation assessment instrument based on the indicators of the BTQ assessment program at IAIN Pekalongan. This type of research is research development with a quantitative descriptive approach. The floating stage includes the preparation of test specifications, expert validation, trials, and product implementation. Data collection techniques and instruments through observation and questionnaires are presented in the form of test items to analyze the suitability of competency standards in each component. The results of this study indicate that 16 items representing BTQ assessment instrument indicators meet valid criteria with the results of the validity of 4 aspects (tajwid, fashohah, gharib, adab) the greatest factor load of 1.05 on the accuracy indicator of reading the law of Imalah and isymam, while the lowest is 0.81 at indicator of reading the Qur'an by closing the genitals. The results of the BTQ instrument construction analysis meet 8 of 9 index criteria of goodness of fit so that it can be used in measuring the ability to read the Qur'an.
\end{abstract}

Keywords: Assessment Instrument, Development Model, Al-Qur'an Writing

\section{Pendahuluan}

Salah satu program dari Ma'had al-Jami'ah Institut Agama Islam Negeri Pekalongan adalah bidang Baca Tulis al-Quran (BTQ), selanjutnya akan disebut BTQ. Pelaksanaan bidang ini berfokus pada program pengembangan tabsinul Qur'an. Lebih spesifik lagi bidang ini secara intens memperbaiki serta mendampingi para mahasiswa dalam mempelajari ilmu tajwidil Qur'an. Secara struktural bidang BTQ yang merupakan salah satu program Ma'had Al-Jami'ah berada dibawah komando Wakil Rektor III (Bidang Kemahasiswaan dan Kerjasama). Pengadaan program ini merupakan salah satu langkah dalam mendorong para mahasiswa IAIN Pekalongan untuk dapat memiliki keilmuan yang qur'ani yang baik. Dimana bentuk keilmuan tersebut dibutuhkan oleh akademisi perguruan tinggi yang memiliki identitas keislaman seperti Institut Agama Islam Negeri (IAIN) Pekalongan.

Latar belakang berdirinya program BTQ, diawali dari hasil pembacaan di lapangan oleh para pimpinan dan dosen yang prihatin dengan kondisi mahasiswa Institut Agama Islam Negeri Pekalongan secara khusus dalam penguasaan keilmuan al-Quran. ${ }^{1}$ Penguasaan keilmuan al-Quran yang seringkali menjadi sorotan yaitu kemampuan membaca kurang fasih dan pemahaman secara parsial. Masalah ini bertentangan dengan idealisme Institut Agama Islam Negeri Pekalongan yang tertuang dalam tagline Spirituality-Scientific. Spirituality-Scientific yang dijadikan idealisme Institut Agama Islam Negeri Pekalongan menuntut mahasiswa untuk memiliki spiritualitas yang tinggi dan keilmuan yang mendalam terlebih keilmuan keagamaan. Hal ini terkait pula dengan Misi

${ }^{1}$ Buku Pedoman BTQ, Kajian Turast, dan Tahfidz, (Pekalongan: t.p., 2017), hal 6 
Institut Agama Islam Negeri Pekalongan yaitu "Menyelenggarakan pendidikan untuk menghasilkan lulusan yang memiliki kecerdasan spiritual, keluasan pengetahuan, kesetiaan terhadap ke-Indonesian, kemandirian dan kepeloporan dalam kehidupan". Hal tersebut menggambarkan sebuah cakupan akan cita-cita idealitas Institut yang ingin menjembatani antar keilmuankeislaman dengan berlandaskan kearifan lokal yang ada di Indonesia.

Program BTQ menyasar seluruh mahasiswa IAIN Pekalongan tanpa terkecuali. Pelaksanaan program ini memiliki otoritas dengan syahadah yang ditandatangani Mudir Ma'had Al-Jami'ah. Oleh karena itu, BTQ merupakan bagian dari unit Ma'had al-Jami'ah dengan tanggung jawab besar di lingkaran IAIN Pekalongan. Berdasarkan kuantitas, semua mahasiswa IAIN Pekalongan harus mengikuti program Matrikulasi BTQ dan dinyatakan lulus BTQ sebelum mengikuti kegiatan Ibadah Tilawah, Ujian Komprehensif, bahkan Munaqosyah. Mahasiswa yang akan mengikuti kegiatan tersebut harus memiliki kompetensi bacaan Qur'an yang baik dibuktikan dengan syahadah BTQ. Sedangkan secara kualitas, BTQ sebagai bagian dari unit Ma'had al-Jami'ah memiliki beban dan tanggung jawab untuk mengurangi angka ketidakmampuan membaca Qur'an di IAIN Pekalongan. Masih banyak mahasiswa IAIN Pekalongan yang belum mampu membaca Qur'an, bahkan satu dua di antara mereka masih membaca dengan mengeja. Oleh karena itu, program ini dibuat untuk mengurangi beberapa masalah tersebut.

Standarisasi program BTQ ditunjukan dengan adanya placement test dan ujian Matrikulasi BTQ sebagai syarat mengikuti kegiatan Ibadah Tilawah, Ujian Komprehensif, bahkan Munaqosyah. Placement test dan ujian Matrikulasi BTQ tentunya tidak terlepas dari kegiatan pengujian kemampuan mahasiswa dalam menguasai komponen-komponen yang menjadi ketentuan kelulusan, dimana pada prakteknya membutuhkan proses pengukuran dan penilaian untuk mengetahui sejauh mana mahasiswa dapat menguasai kompetensi yang ditentukan dalam program Matrikulasi BTQ. Ujian placement test BTQ diperuntukkan bagi semua mahasiswa baru. Sedangkan program Matrikulasi BTQ diperuntukkan bagi mahasiswa yang tidak lulus pada saat placement test BTQ. Ujian Matrikulasi BTQ dilakukan pada dua tahap, UTS dan UAS yang meliputi ujian tertulis dan ujian lisan.

Berdasarkan pada keterangan diatas, jenis pengujian yang dilakukan dalam mengevaluasi hasil pembelajaran tabsinul Qur'an terdiri dari dua jenis. Yaitu tes tertulis dan tes lisan. Kedua jenis tes tersebut tentunya tidak terlepas dari kegiatan pengukuran dan penilaian. Menurut Griffin dan Nix (1991), kegiatan pengukuran, assesmen, dan evaluasi adalah hirarkis. Hirarki disini diartikan sebagai suatu hal yang berkelanjutan, antara satu tindakan diikuti oleh tindakan yang lainnya. Kegiatan pengukuran adalah penentuan skor terhadap suatu keadaan dengan aturan tertentu, kemudian hasil skor diinterpretasikan sehingga menghasilkan suatu nilai yang disebut sebagai penilaian. Adanya proses berkelanjutan ini, dapat dikatakan penilaian dan pengukuran merupakan satu kesatuan yang saling memerlukan (Burhan Nurgiyantoro, 2001: 5). Penilaian mencakup aspek kualitatif dan kuantitatif, sedangkan pengukuran berkaitan dengan aspek kuantitatif. Aspek kuantitatif pada penilaian diperoleh melalui pengukuran, sedangkan aspek kualitatifnya berupa penafsiran dan pertimbangan terhadap data 
kauntitatif hasil pengukuran tersebut. Jadi, penilaian sangat membutuhkan data yang diperoleh dari pengukuran.

Secara teoritik pengukuran adalah kegiatan penetapan angka (skor) dengan cara yang sistematis untuk menyatakan keadaan individu. ${ }^{2}$ Dalam BTQ keadaan individu yang dimaksud berupa kemampuan setiap mahasiswa untuk membaca al-Qur'an dengan baik dan benar berdasarkan pada kaidah ilmu tajwid. Sedangkan penilaian diartikan sebagai kegiatan penafsiran data hasil pengukuran. Pengukuran dapat diperoleh malalui kegiatan pengujian, dalam hal ini dilakukan ujian Placement Test dan Matrikulasi BTQ yang mana akan diperoleh hasil berupa skor. Selanjutnya skor akan diinterpretasikan sebagai hasil dari penilaian. Penilaian berfokus pada individu, sehingga keputusannya juga terhadap individu. Hal tersebut membuat individu akan mendapatkan hasil yang berbeda sesuai dengan kemampuan masing-masing. Misalnya dalam dunia pendidikan, penilaian berfokus pada prestasi belajar yang dicapai oleh individu setiap peserta didik. ${ }^{3}$ Sedangkan dalam ujian Placement Test dan Matrikulasi BTQ terdapat beberapa komponen penilaian antara lain: tahsin bacaan, dan ilmu tajwid.

Tiga komponen yang menjadi ranah penilaian ujian Placement Test dan Matrikulasi BTQ menjadi standar kompetensi yang harus dimiliki oleh mahasiwa yang mana kemampuan dalam penguasaan komponen tersebut ditunjukan dalam ujian lisan dimana pada umumnya setiap pengujian membutuhkan instrumen penilaian. ${ }^{4}$ Instrumen penilaian dalam ujian lisan yang berupa penilaian unjuk kerja tidak lepas dari penilaian rater. Begitu pula pada penilaian ujian lisan, Matrikulasi BTQ yang menggunakan satu orang penilai pada tiap kelompok. Proses penilaian yang melibatkan satu rater pada petunjuk kerja akan mengakibatkan ketidakkonsistenan rater dalam memberikan penilaian pada individu yang berbeda dengan kemampuan yang sama, dengan kata lain hasil penilaian menjadi tidak objektif. Menurut Azwar untuk meminimalkan pengaruh subjektivitas pemberian skor, prosedur penilaian melalui rating dilakukan oleh lebih dari dua orang pemberi rating atau rater. ${ }^{5}$ Sehingga, apabila penilaian hanya dilakukan oleh satu orang maka kemungkinan penilaian menjadi tidak objektif semakin tinggi. Masalah objektivitas ini menjadi sangat menonjol dikarenakan pada penilaian unjuk kerja biasanya menggunakan gambaran umum tentang aspek yang akan dinilai, kemudian subjektivitas rater juga berpengaruh terhadap hasil penilaian individu. Oleh karena itu dalam penilaian ini dibutuhkan instrumen yang baku sebagai alat ukur yang mampu mengukur secara valid dan reliabel.

Sejauh ini, instrumen penilaian yang dikembangkan untuk ujian Placement Test dan Matrikulasi BTQ belum memenuhi syarat validitas dan reliabilitas. Karena dalam penyusunan instrumen belum dilakukan ujicoba untuk validitas dan reliabilitasnya. Aspek penilain terdiri dari jumlah keseluruhan nilai kelancaran membaca, tahsin dan tajwid, keaktifan, tugas, sikap dan kehadiran. Untuk panduan penilaian belum dijelaskan

\footnotetext{
2 Allen Mary, Yen Wendy, Introduction to Measurement Theory, (California: Bookks/Cole Publishing Company, 1979), hal.2 2012), hal.3

3 Mardapi Djemari, Pengukuran, penilaian dan Evaluasi Pendidikan. (Yogyakarta: Nuha Medika,

${ }^{4}$ Buku Pedoman BTQ, Kajian Turast, dan Tahfidz, op.cit, hal. 8

${ }^{5}$ Azwar.s, Reliabilitas dan Validitas (Yogyakarta: Pustaka Pelajar, 2016), hal. 10
} 
secara lebih terstruktur antara hubungan indikator yang menjadi aspek penilaian dengan instrumen penilaian yang digunakan. Selain itu, instrument yang digunakan dalam ujian Matrikulasi BTQ berupa lembar penskoran yang sama. Dampak dari itu semua tidak dapat dipastikan apakah instrumen penilaian sudah dapat mengukur komponen yang hendak diukur atau belum. Dari masalah tersebut, mendorong penulis untuk melakukan penelitian dan pengembangan guna mengkaji secara lebih mendalam mengenai kelemahan-kelemahan model penilaian ujian Matrikulasi BTQ yang digunakan selama ini.

Penelitian Research and Development ini merujuk pada model pengembangan assessmen yang dikembangkan oleh Djemari Mardapi. ${ }^{6}$ yang disesuaikan dengan pengembangan instrument penilaian tabsinul qur'an. Adapun langkah-langkah yang dilakukan dalam prosedur pengembangan assessmen ini adalah menyusun spesifikasi tes, menulis soal tes, menelaah tes, melakukan uji coba tes, menganalisis instrumen tes, memperbaiki tes, merakit tes, melaksanaakan tes, dan menafsirkan hasil tes.

Sampel dalam penelitian ini dengan teknik simple random sampling mahasiswa IAIN Pekalongan semester I dan III yang mengikuti program pembelajaran dan pembimbingan Matrikulasi Baca Tulis al-Qur'an (BTQ). Metode pengumpulan data dan instrumen yang dilakukan pada penelitian ini adalah observasi, angket, dan dokumentasi. Observasi, digunakan untuk mengetahui proses pembelajaran dan pembimbingan tahsinul qur'an dan kegiatan ujian syahadah sampai tahap proses pengujian dan penilaian yang dilakukan. Angket, digunkan untuk menganalisis kebutuhan pengembangan model instrumen penilaian tahsinul qur'an yang akan ditujukan kepada para praktisi sebagai tanggapan mereka setelah menggunakan instrumen penilaian yang dikembangkan. Dokumentasi, digunakan untuk memperoleh data berupa identitas mahasiswa, lembar penilaian sebelumnya untuk memberi gambaran mengenai format penilaian yang sudah digunakan sebelumnya.

Teknis analisis data dilakukan dengan pendekatan kualitatif dan kuantitatif. Kualitatif dilakukan untuk mengetahui efisiensi dan keefektifan penggunaan instrumen penilaian, yang dikembangkan dengan melibatkan pendapat para penguji, tim penilai dan asisten penguji tahsinul qur'an. Kuantitatif dilakukan melalui dua tahap. Pertama, telaah ketepatan butir berdasarkan isi melalui penilaian ahli (expert judgment) sebanyak 8 orang untuk mengetahui ketepatan dimensi penilaian, indikator yang akan digunakan sebagai pedoman penilaian, dan rubrik penskoran. Kedua, analisis data dilakukan dengan menggunakan program LISREL 9.2 dengan kriteria muatan faktor $(>0.5)$ dan nilai $t$ hitung (>1.96). Analisis yang digunakan untuk menentukan indeks validitas isi instrumen dengan menggunkan formula index Aiken's sebagai berikut: ${ }^{7}$

${ }^{6}$ Mardapi Djemari, op.cit, hal. 110

7 Aiken, Three Coefficients For Analyzing The Reliability and Validity of Ratings. Educaional and Psychological Measurement, (1985), hal. 956 
Keterangan:

$$
V=\frac{\sum s}{[n(c-1)]}
$$

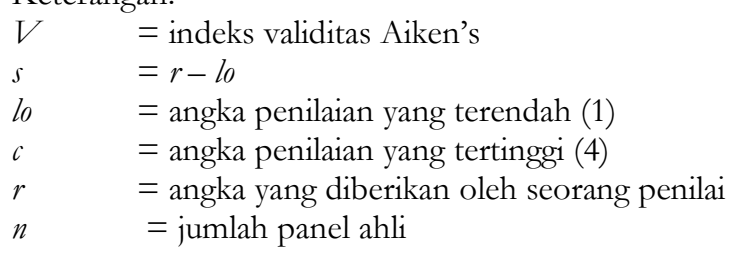

\section{Pembahasan}

\section{A. Hasil Validitas Isi}

Telaah instrumen yang dilakukan dalam mengembangkan konstruk instrumen penilaian BTQ dilakukan secara kuantitatif. Telaah secara kuantitatif dilakukan oleh 8 orang ahli. Tugas ahli dalam hal ini melihat kesesuaian indikator dengan tujuan pengembangan instrumen, kesesuaian indikator dengan cakupan materi atau kesesuaian teori, melihat kesesuaian instrumen dengan indikator butir, melihat kebenaran konsep butir, melihat kebenaran isi, kebenaran kunci. ${ }^{8}$ Ahli memberikan validasi berupa penilaian secara kuantitatif dengan memberikan skor pada lembar validasi mengenai kesesuaian kisi-kisi tes, lembar penilaian dan rubrik penilaian BTQ yang telah tersusun dengan tujuan penilaian BTQ. Berdasarkan skor yang diberikan oleh 8 ahli terhadap 16 butir instrumen, peneliti menghitung hasil kesepakatan ahli dengan formula index Aiken's untuk mengetahui validitasi instrumen penilaian BTQ. ' Hasil perhitungan formula index Aiken's secara lengkap dipaparkan sebagai berikut:

Tabel 1. Hasil Validitasi Melalui Expert Judgment

\begin{tabular}{|l|c|c|}
\hline \multicolumn{1}{|c|}{ No. item } & Nilai V aiken & Keterangan \\
\hline Item1 & 0.71 & Valid \\
\hline Item2 & 0.67 & Valid \\
\hline Item3 & 0.79 & Valid \\
\hline Item4 & 0.75 & Valid \\
\hline Item5 & 0.79 & Valid \\
\hline Item6 & 0.79 & Valid \\
\hline Item7 & 0.67 & Valid \\
\hline Item8 & 0.67 & Valid \\
\hline Item9 & 0.67 & Valid \\
\hline Item10 & 0.71 & Valid \\
\hline Item11 & 0.71 & Valid \\
\hline Item12 & 0.71 & Valid \\
\hline Item13 & 0.71 & Valid \\
\hline Item14 & 0.71 & Valid \\
\hline Item15 & 0.67 & Valid \\
\hline Item16 & 0.71 & Valid \\
\hline
\end{tabular}

${ }^{8}$ Heri Retnawati, Analisis Kuantitatif Instrumen Penelitian, (Yogyakarta: Parama Publishing, 2016)

${ }^{9}$ Aiken, op.cit, hal.56 
Hasil perhitungan indeks Aiken kemudian disesuaikan dengan batas minimal nilai $\mathrm{V}$ pada tabel Aiken. Berdasarkan pada tabel Aiken. ${ }^{10}$ nilai minimal pada 16 butir instrumen dengan 8 rating kategori dan menggunakan tingkat kesalahan sebesar $5 \%$ adalah $\mathrm{V}=0.67$. Hasil perhitungan indeks Aiken yang terdapat pada tabel diatas menunjukkan nilai indeksnya adalah $\geq 0.67$ pada tiap butir, oleh karena itu dapat disimpulkan 16 butir instrumen penilaian BTQ valid dalam mengukur kemampuan membaca Al-Qur'an.

\section{B. Hasil Uji Coba}

Uji coba lapangan dilakukan untuk mengetahui kecocokan antara struktur dimensi instrument secara konseptual dengan data empirik. Uji coba lapangan dilakukan dengan mengujikan instrument penilaian kepada 290 responden mahasiswa sebagai peserta tes BTQ. Analisis data dilakukan dengan menggunakan program LISREL 9.2 dengan kriteria muatan faktor $(>0.5)$ dan nilai t hitung (>1.96). Hasil analisis konstruk instrument penilaian BTQ menunjukkan semua butir memiliki loading faktor yang baik atau dapat dikatakan semua butir valid dan dinyatakan fit. Hal yang menyebabkan hasil belum fit adalah nilai RMSEA yang dihasilkan sebesar 0.056 dengan kriteria dikatakan fit adalah $\leq 0.080$. Indikator tersebut memberikan informasi bahwa dalam data tersebut dinyatakan fit model. Adapun hasil analisis tersebut dapat dilihat pada gambar berikut:

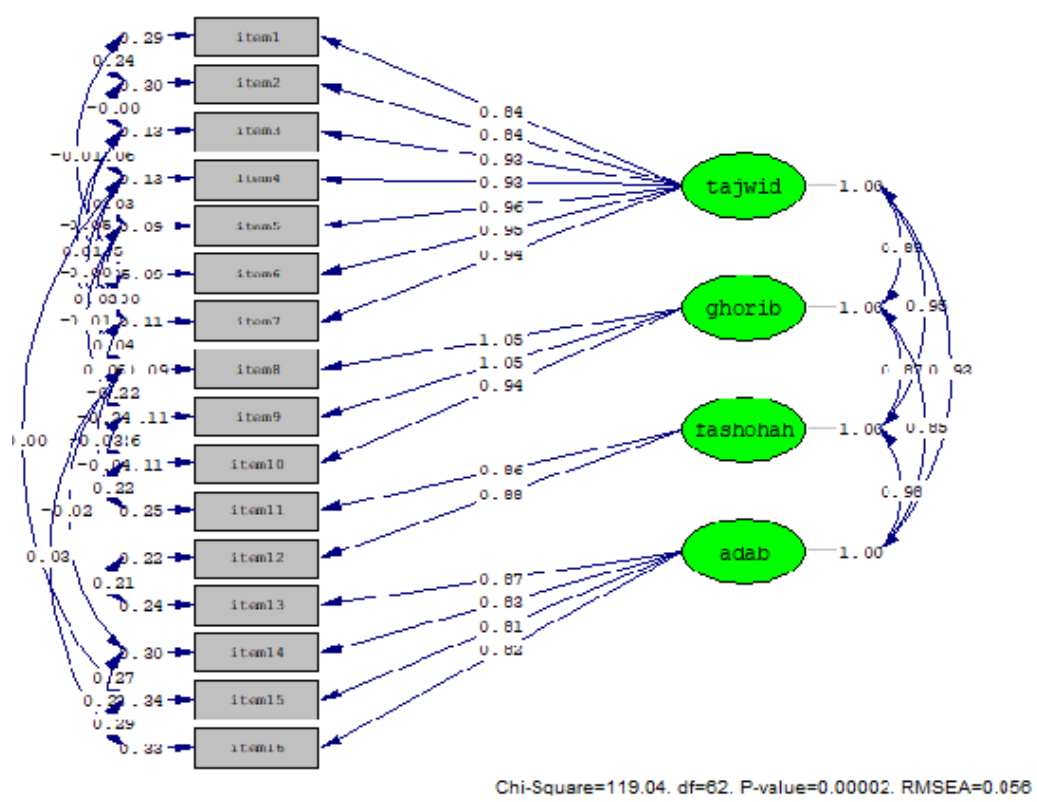

Gambar 1. Nilai Muatan Faktor First Order CFA Konstruk BTQ

${ }^{10}$ Ibid, hal. 134 
Berdasarkan gambar diatas dapat dilihat nilai muatan faktor yang dihasilkan $>0.50$. Hal ini dapat dikatakan semua item dalam instrumen penilaian BTQ memenuhi kriteria untuk dikatakan valid, dan konstruk yang dibangun sesuai dengan data empirik. Oleh karena itu, 16 item yang mewakili indikator dalam instrumen penilaian BTQ dapat digunakan dalam mengukur kemampuan membaca Al-Qur'an. Sementara untuk hasil t hitung dapat dilihat pada gambar berikut:

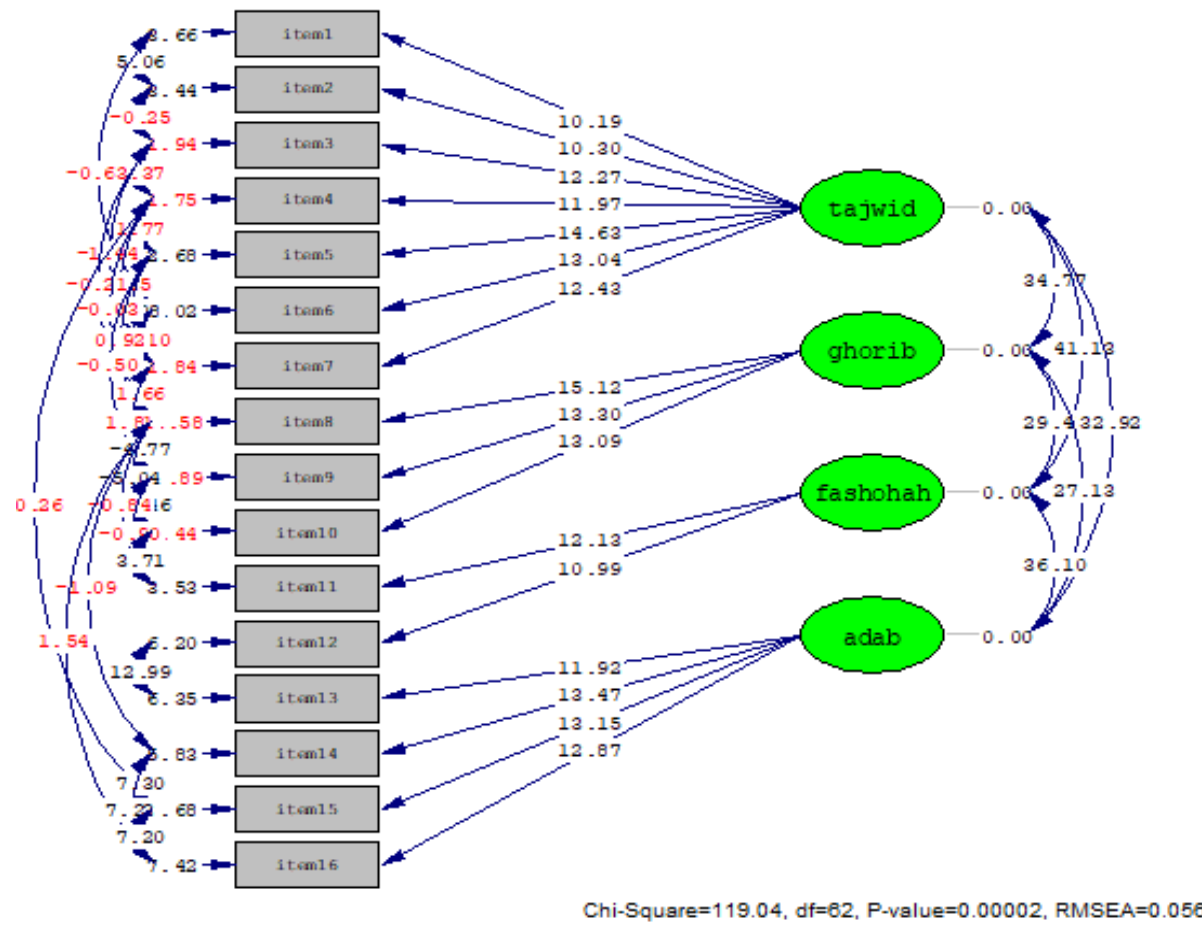

Gambar 2. Nilai t First Order CFA Instrumen BTQ

Berdasarkan gambar diatas, dapat diketahui hasil t-value dari masingmasing item memenuhi syarat signifikansi. Hal tersebut dapat dilihat dari nilai loading factor pada hasil t-value yang menunjukkan nilai lebih besar dari 1.96. Hal ini berarti 16 item yang mengukur kemampuan BTQ, seluruhnya valid dan signifikan terhadap masing-masing dimensi tajwid, ghorib, fashohah, dan adab. Untuk lebih jelasnya akan ditampilkan secara lebih rinci pada table berikut:

Tabel 2. Hasil First Order CFA Validitas Konstruk Instrument BTQ

\begin{tabular}{|c|c|c|c|c|c|}
\hline No & ASPEK & ITEM & MuatanFaktor & $T$-Value & Ket \\
\hline 1 & \multirow{7}{*}{ Tajwid } & Item1 & 0.84 & 10.19 & Sig \\
\hline 2 & & Item2 & 0.84 & 10.30 & Sig \\
\hline 3 & & Item3 & 0.93 & 12.27 & Sig \\
\hline 4 & & Item4 & 0.93 & 11.97 & Sig \\
\hline 5 & & Item5 & 0.96 & 14.63 & Sig \\
\hline 6 & & Item6 & 0.95 & 13.04 & Sig \\
\hline 7 & & Item7 & 0.94 & 12.43 & Sig \\
\hline 8 & \multirow[t]{3}{*}{ Ghorib } & Item8 & 1.05 & 15.12 & Sig \\
\hline 9 & & Item9 & 1.05 & 13.30 & Sig \\
\hline 10 & & Item10 & 0.94 & 13.09 & Sig \\
\hline 11 & Fashohah & Item11 & 0.86 & 12.13 & Sig \\
\hline
\end{tabular}




\begin{tabular}{|l|l|l|l|l|l|}
\hline 12 & & Item12 & 0.88 & 10.99 & Sig \\
\hline 13 & \multirow{3}{*}{ Adab } & Item13 & 0.87 & 11.92 & Sig \\
\cline { 4 - 6 } & & Item14 & 0.83 & 13.47 & Sig \\
\hline \multirow{2nnyyy}{*}{15} & Item15 & 0.81 & 13.15 & Sig \\
\hline \multirow{2nnyyy}{*}{16} & & Item16 & 0.82 & 12.87 & Sig \\
\hline
\end{tabular}

Berdasarkan table diatas dapat diketahui item yang memiliki nilai muatan faktor paling besar adalah pada item 8 dan item 9 dengan nilai loading factor sebesar 1.05, kedua item ini merupakan item yang mengukur kemampuan pada aspek ghorib dengan masing-masing indikatornya adalah ketepatan membunyikan hukum bacaan imaalah dan ketepatan membunyikan bacaan isymaam. Sedangkan untuk nilai item yang memiliki loading factor paling rendah adalah item 15 yaitu sebesar 0.81. Indikator item 15 adalah membaca al-qur'an dengan menutup aurat. Berdasarkan nilai yang terdapat pada table diatas dapat diketahui juga item 8 memberikan sumbangsih signifikansi yang besar dilihat dari nilai t-value yang dihasilkanya itu sebesar 15.12 .

Setelah dilakukan uji pengukuran untuk melihat besar nilai muatan faktor pada masing-masing item, selanjutnya uji pengukuran ini dilakukan untuk melihat kesesuain model (model fit). Kesesuaian model dapat dilihat dari nilai goodness of fit, di mana terdapat beberapa indikator untuk melihat goodness of fit index. Adapun hasil dari nilai goodness of fit yang diperoleh dalam analisis konstruk instrumen penilaian BTQ adalah sebagai berikut:

Tabel 3. Kriteria Model Fit pada Konstruk Instrumen Penilaian BTQ

\begin{tabular}{|l|l|c|c|c|}
\hline \multicolumn{1}{|c}{ Indicator } & \multicolumn{1}{|c|}{ KET. Indictor GOFI } & $\begin{array}{c}\text { Nilai standar } \\
\text { untuk kecocokan } \\
\text { baik }\end{array}$ & $\begin{array}{c}\text { Hasil } \\
\text { hitung }\end{array}$ & Kesimpulan \\
\hline RMSEA & $\begin{array}{l}\text { Root mean square error of } \\
\text { approximation }\end{array}$ & $\leq 0.08$ & 0.056 & Kecocokan baik \\
\hline NFI & Normed fit index & $\geq 0.09$ & 0.985 & Kecocokan baik \\
\hline NNFI & Non-normed fit index & $\geq 0.09$ & 0.986 & Kecocokan baik \\
\hline CFI & Comparative fit index & $\geq 0.09$ & 0.993 & Kecocokan baik \\
\hline IFI & Incremental fit index & $\geq 0.09$ & 0.992 & Kecocokan baik \\
\hline RFI & Relative fit index & $\geq 0.09$ & 0.972 & Kecocokan baik \\
\hline Std.RMR & $\begin{array}{l}\text { Standardized root mean square } \\
\text { residuan }\end{array}$ & $\leq 0.05$ & 0.021 & Kecocokan baik \\
\hline GFI & Goodness of fit index & $\geq 0.09$ & 0.952 & Kecocokan baik \\
\hline AGFI & Adjusted goodness of fit index & $\geq 0.09$ & 0.895 & $\begin{array}{c}\text { Kecocokan tidak } \\
\text { baik }\end{array}$ \\
\hline
\end{tabular}

Berdasarkan hasil analisis yang dipaparkan dalam tabel diatas dapat diketahui konstruk instrumen BTQ memenuhi 8 dari 9 indeks kriteria goodness of fit untuk dikatakan bahwa model fit atau memiliki kecocokan yang baik. Artinya, dari hasil ini dapat dikatakan bahwa model teoritik dimensi pengukuran penilaian BTQ sesuai atau fit dengan data empirik. Berdasarkan hasil analisis validitas konstruk maka semua item yang membentuk aspek-aspek yang mengukur kemampuan membaca Al-Qur'an dalam instrumen penilaian BTQ dinyatakan valid. 


\section{Catatan Akhir}

Berdasarkan hasil penelitian mengenai pengembangan instrumen penilaian BTQ di Institut Agama Islam Negeri Pekalongan secara umum dapat ditarik kesimpulan bahwa instrumen penilaian BTQ yang telah dikembangkan melalui proses validasi dinyatakan telah memenuhi validitas isi dan validitas konstruk yang ditentukan oleh para ahli/pakar maka perangkat penilaian BTQ ini valid. Sementara hasil uji coba yang dilakukan, diperoleh nilai konsistensi kriteria muatan faktor yang dihasilkan $>0.50$. Hal ini dapat dikatakan semua item dalam instrumen penilaian BTQ memenuhi kriteria untuk dikatakan valid, dan konstruk yang dibangun sesuai dengan data empirik. Sementara untuk hasil t hitung dari masing-masing item memenuhi syarat signifikansi. Hal tersebut melihat dari nilai loading factor pada hasil t-value yang menunjukkan nilai lebih besar dari 1.96.

\section{Daftar Rujukan}

Aiken, (1985). Three Coefficients For Analyzing The Reliability and Validity of Ratings. Educaional and Psychological Measurement

Allen, Mary., \& Yen, Wendy. (1979). Introduction to Measurement Theory. California: Bookks/Cole Publishing Company.

Azwar, S. (2010). Dasar-dasar Psikometri. Yogyakarta: Pustaka Pelajar.

Azwar. S. (2016). Reliabilitas dan Validitas.Yogyakarta: Pustaka Pelajar.

Bahrudin, Kumaidi. (2014). Model Asesmen Musabaqah Tilawah Al-Qur'an (MTQ) Cabang Tilawah. Jurnal Penelitian dan Evaluasi Pendidikan, Nomor 2.

Djaali, Muljono, P. (2008). Pengukuran dalam Bidang Pendidikan. Jakarta: Penerbit PT Grasindo

Griffin, Patrix., \& Nix, Peter. (1991). Educational Assesment and Repoting. Sydney: Harcout Brace Javanovich, Publisher.

Gronlund, N.E. \& Linn, R.L. (1990). Measurement and Evaluation in Teaching. New York: MacMillan Publishing Company.

Haryanto. Cahyani.(2015). Pengembangan Aplikasi Mutabaah Tabfidr. Al-Qur'an untuk. Mengevaluasi Hafalan. Jurnal Algoritma Sekolah Tinggi Teknologi Garut Vol. 12 No. 1

Heri Retnawati. (2016). Analisis Kuantitatif Instrumen Penelitian, Yogyakarta: Parama Publishing

Mardapi, Djemari. (2012). Pengukuran, penilaian dan Evaluasi Pendidikan. Yogyakarta: Nuha Medika

Nurgiyantoro Burhan. (2001). Penilaian dalam Pengajaran Babasa dan Sastra. Yogyakarta: BPFE-Yogyakarta

Reynolds, C.R., Livingston, R.B., \&Willson, V. (2010). Measurement and Assessment in Education. New Jersey: Pearson Education, Inc 